Working Paper/Document de travail

2007-33

\title{
Domestic versus External Borrowing and Fiscal Policy in Emerging Markets
}

by Garima Vasishtha 
Bank of Canada Working Paper 2007-33

May 2007

\title{
Domestic versus External Borrowing and Fiscal Policy in Emerging Markets
}

\author{
by \\ Garima Vasishtha \\ International Department \\ Bank of Canada \\ Ottawa, Ontario, Canada K1A 0G9 \\ gvasishtha@bankofcanada.ca
}

Bank of Canada working papers are theoretical or empirical works-in-progress on subjects in economics and finance. The views expressed in this paper are those of the authors.

No responsibility for them should be attributed to the Bank of Canada. 


\section{Acknowledgements}

I am indebted to Kenneth Kletzer for his invaluable support and guidance during the course of this project. I would also like to thank Joshua Aizenman, Don Coletti, Denise Côté, Carlos De Resende, Michael Hutchison, Brent Haddad, Thorsten Janus, Robert Lafrance,

Robert Lavigne, Danielle Lecavalier, Lawrence Schembri, and Nirvikar Singh for helpful comments and suggestions. All remaining errors are my own. 


\begin{abstract}
Domestic public debt issued by emerging markets has risen significantly relative to international debt in recent years. Some recent empirical evidence also suggests that sovereigns have defaulted differentially on debt held by domestic and external creditors. Standard models of sovereign debt, however, mainly focus on how the actions of foreign creditors influence default decisions of sovereigns. Contrasting this one-sided focus, this paper adds to a new theoretical literature that points at the possibility of default on domestic debt and the consequences of doing so. It presents a model of an emerging market economy in which the government can selectively default on its domestic or external debt obligations. The model shows that the differential ability of domestic and foreign creditors to punish the government creates a gap in the expected default costs to the sovereign, and hence a differential in its propensity to default on its domestic versus foreign debt. The extent to which the possibility of differential treatment of creditors affects the composition of debt is explored. It shows that a country characterized by volatile output, sovereign risk, and costly tax collection will want to borrow in domestic markets as well as in international capital markets. The optimal allocation of debt between domestic and foreign creditors can thus be viewed as the government's purchase of insurance against macroeconomic shocks that affect its budget.

JEL classification: F30, H21, H63

Bank classification: Debt management; International topics
\end{abstract}

\title{
Résumé
}

L'encours de la dette intérieure des économies émergentes a sensiblement augmenté ces dernières années par rapport à celui de leur dette extérieure. De récents travaux empiriques tendent aussi à indiquer que les débiteurs souverains n'honorent pas leurs engagements à l'endroit de leurs créanciers nationaux de la même façon qu'envers leurs créanciers internationaux. Dans les modèles habituels de la dette souveraine, toutefois, les chercheurs s'attachent surtout à déterminer comment les actions des créanciers étrangers influent sur la décision des États de respecter ou non leurs obligations. En contraste avec cette approche unidimensionnelle, l'auteure inscrit son étude dans un nouveau courant théorique qui s'intéresse à la possibilité de défaillance à l'égard de la dette intérieure et à ses implications. Elle présente le modèle d'un pays à marché émergent dont le gouvernement peut choisir de ne pas assurer le service de sa dette intérieure ou extérieure. Selon ce modèle, l'aptitude inégale des créanciers résidents et non résidents à sanctionner l'État défaillant explique l'écart observé entre les coûts de défaut attendus pour le débiteur souverain et, 
par conséquent, la propension de ce dernier à privilégier l'une ou l'autre catégorie de ses créanciers. L'auteure tente d'évaluer si la différence de traitement à laquelle seraient soumis les créanciers influe sur la structure de la dette. Elle montre qu'un pays qui se caractérise par une production très variable, un risque souverain et des coûts de perception élevés des impôts préférera emprunter à la fois sur son propre marché et sur les marchés financiers internationaux. La répartition optimale des emprunts entre prêteurs résidents et non résidents peut donc être assimilée à la souscription par l'État d'une police d'assurance contre les chocs macroéconomiques susceptibles de frapper son budget.

Classification JEL : F30, H21, H63

Classification de la Banque : Gestion de la dette; Questions internationales 


\section{Introduction}

Debt markets in emerging economies have expanded considerably since the mid-1990s. Domestic debt securities, in particular, have experienced considerable growth during this period. By late 2004, the stock of domestic debt securities issued by emerging economies reporting data to the BIS reached US\$2.8 trillion and was four times larger than the corresponding amount of international debt securities (US\$ 0.7 trillion). As a proportion of GDP, the stock of domestic debt securities issued by emerging markets has almost doubled since the mid-1990s, and stood at 40 percent in $2004 .^{1}$

The increasing significance of public sector bonds issued in domestic markets argues for the importance of analyzing the considerations that affect a government's decision to borrow from home or abroad. The optimal composition of debt between domestic and external components is an issue which has received little attention in the sovereign debt literature. It has been argued that the decision of where to issue debt reflects the characteristics of domestic capital markets. That is, countries that are characterized by poorly developed capital markets or low supply of domestic savings may be forced to borrow in the foreign markets. However, the focus of this literature is on why countries may be forced to issue foreign debt when domestic capital markets are not well developed. It does not focus on why governments may choose to borrow at home (or abroad) when they have the option of issuing debt in either market. This paper is an attempt towards providing an explanation for the latter.

This issue is particularly relevant in the light of recent developments in debt markets. With the liberalization of capital flows and the increasing sophistication of domestic financial markets, developing country residents are buying more and more of their governments' debt. In the event of a debt restructuring, domestic residents figure as borrowers and as creditors, thus appearing on both sides of the negotiating table. The tasks of debt restructuring are further complicated in today's emerging market sovereign debt world, as the structure and patterns of holding debt instruments becomes increasingly complex. As a result, in contrast to the default episodes of the 1980s, the episodes of the 1990s left open many more margins on which a country experiencing repayment difficulties had to make decisions. Countries had to decide

\footnotetext{
${ }^{1}$ Source: BIS and IMF
} 
which instruments they would default upon. For example, while Argentina and Ecuador defaulted on all debt instruments, Russia, Ukraine and Pakistan defaulted on only a few instruments.

Countries also had to decide whether to default on debt held by domestic creditors or on that held by foreign cre ditors. Foreign debt is often taken to be synonymous with foreigncurrency denominated debt, domestic debt with domestic-currency denominated debt. However, the currency denomination and the nationality of investors do not necessarily match. ${ }^{2}$ Indeed, in some cases it is difficult to distinguish between domestic and foreign creditors because, with highly integrated world capital markets, who ultimately ends up holding the debt is independent of where the government issues it. However, as pointed out by Drazen (1998), it is important to distinguish between domestic and external debt for two reasons. First, governments face different incentives in repaying debts held by residents and nonresidents. ${ }^{3}$ Second, governments can influence to some extent whether bonds are held by domestic residents or nonresidents. Interest differentials can sometimes be observed on identical debt instruments issued at home versus abroad. Some debt instruments are clearly segmented in terms of their bearers. ${ }^{4}$

In addressing the above stated issues, this paper is structured as follows. Section 2 provides a discussion of the theoretical and empirical motivation for the paper. Section 3 reviews the related literature. Section 4 presents the benchmark theoretical model where the government

\footnotetext{
2 According to the "economic" definition (based on a residency principle), foreign debt is only the debt by nonresidents, regardless of whether the debt is in local or foreign currency, whether it is issued at home or abroad. Conversely, domestic debt is debt by residents, regardless of whether the debt is in local or foreign currency, whether it is issued at home or abroad. According to the "legal" definition, domestic debt is defined as debt issued according to domestic law, regardless of whether it is in local or foreign currency and regardless of who, foreign or domestic residents, is holding these claims. Conversely, the "legal" definition of foreign debt $\dot{\mathbf{s}}$ debt issued according to foreign law, regardless of whether it is in local or foreign currency and regardless of who is holding these claims.

${ }^{3}$ Kremer and Mehta (2000) note that there is historical evidence that the repayment decisions of sovereigns are conditioned on the identity of their creditors. They suggest that "a large amount of domestic-currency-denominated foreign debt borne by a government is said to raise suspicions that the government will pursue inflationary policies. Thus, speculative attacks against the French franc in the 1920s have been blamed on expectations that the government would try to inflate away its foreign debt obligation from World War I." (Kremer and Mehta (2000), pp 4)

${ }^{4}$ Governments do issue debt that is differentially targeted to domestic or foreign creditors; for example, many countries issue sovereign bonds that are non-transferable or difficult to transfer. Domestic currency denominated debt may likewise be more attractive to domestic investors than foreign investors.
} 
can credibly commit to repaying its domestic and external obligations. Section 5 focuses on incentive problems, and selective default on one class of debt obligations. Section 6 concludes.

\section{Motivation}

The motivation for this study is two-fold. The theoreticalmotivation stems from the fact that the vast literature on sovereign debt mostly ignores the distinction between domestic and foreign borrowing, with most papers addressing only external debt. ${ }^{5}$ Furthermore, most studies of sovereign external debt assume that the capacity to raise foreign exchange is the binding constraint in the sovereign's repayment decision. On the other hand, several authors have focused on the fiscal constraint, recognizing that the repayment of foreign debt- which is primarily owed by the government- is financed by the transfer of resources from the private to the public sector. ${ }^{6}$ This paper focuses on the second approach. To these fiscal constraints, this paper adds another crucial element: the service of the domestic debt. This is done by focusing on the problem of raising domestic revenue through distortionary taxation in order to service government debt obligations. Governments need to make adjustments on both the external and domestic fronts in order to service their external debt obligations. The external adjustment involves running a trade surplus by subsidizing exports, rationing of imports, and real devaluations. The domestic adjustment requires raising taxes and incurring the social cost of distortionary taxation required for servicing the debt. If this 'secondary burden' of raising taxes is not borne, then domestic debt will simply replace external debt over time. This, in turn, could have serious repercussions for the economy (Cohen, 1987).

Another strand of literature that this study draws on is the optimal taxation approach towards debt management. In recent years, research on debt management has made significant progress, focusing on debt structure by denomination, indexation features and maturity, with the results relying heavily on the optimality of tax smoothing. ${ }^{7}$ However, little attention has been paid to the question of whether debt should be issued at home or abroad, and the factors that influence the choice of borrow ing from domestic or foreign markets. This paper uses the optimal taxation approach to analyze this issue. The crucial difference, however, between the

\footnotetext{
${ }^{5}$ Exceptions are Cohen (1991), Drazen (1998), and Kremer and Mehta (2000).

${ }_{7}^{6}$ Reisen and van Trotsenberg (1988), Easterly (1989), Guidotti and Kumar (1991), and Dooley and Stone (1993).

7 See Bohn (1988), Calvo (1988), Calvo and Guidotti (1990;1992), Bohn (1990), and de-Fontenay et al. (1995).
} 
conventional analysis of optimal taxation and the present model is the introduction of country risk considerations. This paper develops a model of segmented markets in which the government can selectively default on one class of its obligations (i.e. domestic or foreign), and such default is costly. The focus is on the problem of raising domestic revenue in order to service government debt obligations. The government is assumed to manage its debt to minimize the expected present value of the distortions from financing its expenditures. The ultimate goal of the model is to characterize the optimal debt structure chosen by the sovereign.

Thus, this paper expands the existing literature in two directions. First, it goes beyond external debt and explicitly considers the crucial issue of domestic debt service faced by a sovereign. Second, it builds on the conventional analysis of optimal taxation by considering the possibility of default on domestic and/or external debt. The option of defaulting brings partial state contingency to the economy.

The second source of motivation is derived from recent sovereign default episodes, some of which clearly highlight a differential treatment between domestic and foreign creditors. In a recent paper, Sturzenegger and Zettelmeyer (2004) study whether investors were treated equally in recent debt restructurings, or if some instrument holders came out better than others. Their main results show that some (but not all) exchanges studied exhibit substantial variations in the "haircut" even within the same exchange, depending on the instrument tendered. Thus in most cases, "intercreditor equity" was violated ex post, at least in a present value sense. The recent default episodes in Argentina and Russia, briefly outlined below, show some interesting patterns with regards to the treatment of domestic and foreign bondholders.

\section{Argentina $^{8}$}

In November 2001, after a substantial fall in tax collection, the Finance Minister, Domingo Cavallo, announced that he would seek debt relief in a voluntary manner and in two stages. The first stage (Phase I) would be targeted at local bondholders, and the second (Phase II) at foreigners. Bond prices plummeted soon after this announcement. In the end, Phase I did happen but soon thereafter the government was ousted in a civilian coup and decided on a

\footnotetext{
${ }^{8}$ See Sturznegger (2002) for an exhaustive account of recent sovereign defaults.
} 
broader default. As a result, Phase II never materialized. The Phase I debt exchange was designed to allow local bondholders to swap their bonds for a guaranteed loan governed by Argentine law, the guarantee being the resources collected by the financial transaction tax. Moreover, local bondholders had the option of recovering the original bonds in the event of any change in the terms and conditions of the guaranteed loans. The bond exchange was extremely successful with almost all the debt in the hands of banks, local pension funds and local residents being tendered. The exchange was aimed at segmenting local and external bondholders, thus protecting the local financial institutions and local pension funds by offering them a better debt instrument, i.e. a guaranteed $\operatorname{loan}^{9}$. However, the domestic bond exchange was considered a technical default by rating agencies, and S\&P moved Argentina to the selective default (SD) category.

On December 24, 2001 Argentina announced the suspension of all payments on all debt instruments. The default was unique in that all claims were declared in default, even before being in default legally. The Argentinean case is alsointeresting because 60 percent of debt was held by Argentines themselves. Sturzenegger and Zettelmeyer (2004) note that "domestic investors that tendered their instruments in Argentina's 'Phase 1' exchange did not fare much better on average, as they were restructured twice, in November of 2001 and February 2002 (pesification). The average cumulative haircut resulting from these two restructurings was close to 70 percent....."10

\section{Russia}

Russia's debt situation deteriorated from late 1997 and continued to worsen through 1998. In order to ease pressures in the GKO market and to reduce interest costs, the government announced a large swap of GKOs for Eurobonds in mid-July 1998. ${ }^{11}$ On August 17, less than a month after the swap was completed, pressures mounted and a default on GKOs was announced. That same day the Russian authorities unilaterally declared a moratorium on all rubledenominated public debt falling due through the end of 1999. In order to ease the pressures on

\footnotetext{
${ }^{9}$ However, it is not clear whether this guarantee actually had any effect as government debt is always guaranteed by tax collection.

${ }^{10}$ Sturzenegger and Zettelmeyer (2004), pp 49.

${ }^{11}$ GKOs were ruble-denominated, short-term treasury bills with maturities of up to twelve months.
} 
the exchange rate and the banking system, external debt obligations were subject to a threemonth moratorium. At the time of default, Russia's public debt stood at less than 60 percent of GDP. External debt was about 45 percent of GDP, with Soviet era debt comprising about twothirds of this amount. Domestic debt amounted to approximately 15 percent of GDP, consisting mostly of short-term GKOs. ${ }^{12}$ It is estimated that about Rub 190 billion in GKO/OFZs was affected by the restructuring, of which over Rub 80 billion was held by non-residents.

The actual default in August 1998 was somewhat unique in modern economic history. The initial announcement did not include a formal declaration of default on external debts. The default on external debt came later, although it was not a surprise, given the poor history of repayments. ${ }^{13}$ Nevertheless, the key element in the emergency package was a restructuring of domestic (ruble) debt. The government's decision to default was unprecedented and clearly controversial, as no country in modern history had ever defaulted on a bond that was denominated in its local currency and was subject to its local law. In the past, when faced with a similar situation, other countries simply eliminated their domestic currency debt problem by printing money, effectively inflating away the issue. The Russian authorities' motivation for the default on domestic debt when other options were available is an open question. One possible explanation is an anti-inflationary bias on part of the authorities at the time the decision was made. ${ }^{14}$ This anti-inflationary bias could possibly have resulted from the prolonged phase of economic contraction, high inflation and depreciation that marked the early 1990s. Another explanation is that concerns about the lack of private sector involvement in Russia motivated the authorities to default on domestic debt obligations. ${ }^{15}$

The Russian debt restructuring is an illustration of the sovereign's tendency of treating domestic and external creditors differently. A month after the default, on September 14, the

\footnotetext{
${ }_{12}^{12}$ This breakdown between external and domestic debt is based on the currency criterion.

${ }^{13}$ It is important to note that, prior to default, the government had proposed to exchange GKOs owned by nonresidents for 5-yr bonds with interest rates slightly above Libor. The residents would have received 3-yr Ruble bonds with a $30 \%$ rate. This dual treatment of the two categories of bondholders was rejected by the IMF as discriminatory.

${ }^{14}$ See IMF (2003)

${ }^{15}$ During the time of the Russian default, there was a perception that the private sector had not contributed adequately during the Asian crisis. It was believed that the "big packages" from the IMF to Thailand, Indonesia and Korea had only served to bail out private investors.
} 
central bank issued three short-term zero-coupon bonds (KBOs) which were exchanged for frozen GKOs and OFZs held by a small number of Russian banks. These bonds were issued without any prior public notification, and violated the sovereign's previous commitments to equal treatment of domestic and foreign investors. ${ }^{16}$

Thus, the default episodes discussed above demonstrate that sovereigns do not necessarily default in the same way on debt held by domestic and external creditors. The theory in this paper attempts to capture this selectivity by focusing on the distinction between domestic and external debt, rather than modeling aggregate public debt. The paper attempts to explore the extent to which the possibility of differential treatment of creditors affects the composition of sovereign debt.

\section{Related Literature}

While the voluminous theoretical literature on sovereign debt focuses on the enforcement technology available to foreign creditors, scant attention has been paid to the domestic creditors. The distinction between the domestic and external debt obligations of a sovereign has largely gone unaddressed. This section briefly outlines some studies that have analyzed this issue.

Cohen (1987) is the first to introduce a distinction between internal and external borrowing in order to address the issue of garnering domestic revenue to finance debt repayment. The paper compares Brazil's and Mexico's adjustment during 1983-85, and concludes that the secondary burden of raising domestic taxes was borne by Mexico but not by Brazil. The repayment strategy adopted by Brazil during this period resulted in an excessive increase in her domestic debt and pushed up the interest rate. However, Cohen's analysis does not cons ider the possibility of debt repudiation.

Drazen (1998) highlights the role of political determinants, specifically the importance of the very different political rights enjoyed by domestic residents versus foreigners, in the decision of where to issue debt. The model is one of segmented markets in which the government acts as

\footnotetext{
${ }^{16}$ As documented in Sturzenegger (2002), Russia had signed various investment protection treaties with the US, UK, Germany and Netherlands in 1989. These treaties dictated equal treatment of foreign and domestic investments.
} 
a discriminating monopsonist in placing its debt, and in which it can selectively repudiate one class of its obligations (i.e. domestic or foreign). The government's decision to repudiate or renegotiate its debt depends on the identity of its claimants through the different political rights they enjoy, and the punishments they can exact if the government fails to meet its obligations. A difference in the political rights of domestic and foreign residents implies that the effective cost of borrowing at home and abroad may differ substantially, with the composition of the debt reflecting the politically determined terms of borrowing. The two key determinants of equilibrium borrowing in Drazen's model are the level and distribution of income, and the severity of penalties for non-repayment.

Kremer and Mehta (2000) examine the effect of reduced transactions costs in the international trading of assets on the ability of governments to issue debt. They examine a model in which governments care about the welfare of their citizens, and thus are more inclined to default if a large proportion of their debt is held by foreigners. They argue that if a government faces different groups of potential creditors, and its ability to commit to repay its debt varies across those groups, then market exchanges of debt between the groups may make it more difficult for the government to commit to repay. Thus, a reduction of transaction costs in asset markets may, paradoxically, reduce a government's ability to commit to repay its debt, worsen its terms of credit, and reduce its welfare.

\section{The Model}

Consider a two-period model of an emerging market economy with two kinds of public debt: Debt held by domestic residents, denoted by $B$, referred to as 'domestic debt' henceforth, and debt held by external creditors, denoted by $F$. Both types of debt are real, i.e. denominated in foreign currency. The main focus is on a non-monetary economy, so the composition of public debt abstracts from interactions with inflation and monetary policy. Nominal debt and inflationary default are not dealt with here. There are three types of agents: domestic consumers (bondholders), foreign creditors and the government. The country's problem is to decide how much to borrow from domestic and external markets. 
The creditor side of the market cons ists of many small bondholders. Owing to their large number, investors can't coordinate among themselves. There are restrictions on private domestic creditors borrowing and lending abroad, so that government bonds are the only saving vehicle. This may approximate the situation in countries with capital controls. We also assume that foreigners cannot borrow from or lend to private domestic residents. This assumption captures the premise that the government has control over the ownership of debt. The fact that all debt is government held can also be explained via sovereign risk. In the context of international lending, lenders have very little ability to assess the solvency of an individual private borrower in a developing country. Foreign lenders are able to penalize the country as a whole for nonrepayment more easily than to impose sanctions on an individual private borrower in that country. Thus foreigners may not lend to the private sector directly but only if the government guarantees the debt.

There are two periods. In period 1 the government can choose between various combinations of tax and debt financing. In period 2 only taxes are available to finance both debt repayments and expenditure on the public good. To simplify the analysis we consider the case where the initial outstanding domestic and external debt is zero. Also, the volume of real government expenditure is assumed to be exogenous, and thus the present analysis abstracts from the choice of the level and composition of government expenditures.

\subsection{Domestic Creditors}

The economy is inhabited by a large number of identical individuals. Each individual lives for two periods and saves by holding government bonds. Though the government has access to foreign financial markets, private agents have access only to the domestic financial market in this model.

Individuals derive utility from consumption in both periods as well as from government spending, $G$. However, individuals take fiscal policy as given and thus the amount of public good produced is beyond the private sector's domain. The representative consumer maximizes the following intertemporal utility function: 


$$
U=\sum_{i=1}^{2} \delta^{\mathrm{i}-1}\left[u\left(C_{i}\right)+v\left(G_{i}\right)-W\left(\Gamma_{i}\right)\right]
$$

with respect to $C_{1}$ and $C_{2}$, where $C_{i}\{i=1,2\}$ denotes the period $i$ consumption of the representative individual, and $W\left(\Gamma_{i}\right)\{i=1,2\}$ denotes the excess burden of taxation in period $i$. $G_{i}\{i=1,2\}$ denotes the volume of real government expenditure, excluding interest payments on the public debt, and is assumed to be exogenous. We assume that the utility derived from consuming $C_{i}, u\left(C_{i}\right)$, is separable from the utility derived from provision of public goods, denoted by $v\left(G_{i}\right)$. The utility index $u$ is assumed to be strictly increasing and $\delta \in(0,1)$ is the discount factor. The maximization problem is subject to the following budget constraints:

$$
\begin{aligned}
& C_{1}=Y_{1}-\Gamma_{1}-W\left(\Gamma_{1}\right)-S_{1} \\
& C_{2}=\left(1+r_{b}\right) S_{1}+Y_{2}-\Gamma_{2}-W\left(\Gamma_{2}\right)
\end{aligned}
$$

where, $S_{1}$ denotes the individual's savings in the first period, $\Gamma_{i}\{i=1,2\}$ denotes the tax revenue obtained by the government in period $i, Y_{i}\{i=1,2\}$ is the exogenous income in period $i$, and $r_{b}$ is the domestic interest rate. Equations (2) and (3) can be combined into the following intertemporal budget constraint:

$$
C_{1}+\frac{C_{2}}{1+r_{b}}=Y_{1}+\frac{Y_{2}}{1+r_{b}}-\left(\Gamma_{1}+W\left(\Gamma_{1}\right)+\frac{\Gamma_{2}}{1+r_{b}}+\frac{W\left(\Gamma_{2}\right)}{1+r_{b}}\right)
$$

The left-hand side of equation (4) is the present discounted value of consumption. The right-hand side is wealth, that is, the present discounted value of the future stream of income minus taxes. The discount rate used to calculate the present discounted values is the domestic interest rate.

The representative consumer's problem is to maximize, with respect to $\left(C_{1}, C_{2}\right)$, the utility function in equation (1) subject to constraint (4). The first order conditions imply the following familiar Euler equation: 


$$
u^{\prime}\left(C_{1}\right)=\delta\left(1+r_{b}\right) u^{\prime}\left(C_{2}\right)
$$

Equations (4) and (5) thus determine the private sector's intertemporal consumption pattern $\left(C_{i}\right)$ as a function of the domestic interest rate and wealth.

\subsection{Foreign Creditors}

The mass of foreign lenders comprises a large number of risk-neutral investors. Two assets (with a one-period maturity) are available to these investors: a government bond yielding an interest rate of $r_{f}$, and the choice to invest in international capital markets and earn the net risk-free return denoted by $r^{*}>0$. The international investor's holdings of government bonds and risk-free international assets at period $i$ are denoted by $F_{i}$ and $x_{i}^{*}$, respectively. Foreign creditors are assumed to have perfect information regarding the economy's endowment process, and can observe the endowment levels each period. Since foreign creditors are assumed to be risk neutral and perfectly competitive, their profits will be zero in expected terms. Under precommitment, their problem can be characterized as follows:

$$
\underset{\left\{c_{1}^{*}, c_{2}^{*}, x_{1}^{*}, F_{1}\right\}}{\operatorname{Max}} \quad U^{*}=u\left(c_{1}^{*}\right)+\delta u\left(c_{2}^{*}\right)
$$

subject to

$$
\begin{aligned}
& c_{1}^{*}=a_{0}^{*}-x_{1}^{*}-F_{1} \\
& c_{2}^{*}=\left(1+r^{*}\right) x_{1}^{*}+\left(1+r_{f}\right) F_{1}
\end{aligned}
$$

where, $a_{0}^{*}$ is the initial wealth, and $c_{i}^{*}$ denotes the consumption of investors in period $i$.

\subsection{The Government}

The focus is on a benevolent government which seeks to maximize the welfare of its citizens, and which takes account of the impact of taxes on welfare. There is an asymmetry in the sovereign borrower's treatment of domestic and foreign creditors. Domestic creditors are 
favored in the sense that their welfare figures into the government's objective function, and hence into its repayment decision. Foreign creditors are disfavored in the sense that the effect of default on foreign creditors' welfare does not affect the government's repayment decision directly. The effect of default on foreign debt only figures indirectly as the penalty which captures the punishment capability of foreigners. ${ }^{17}$

The key idea is that taxes are distortionary and the gove rnment minimizes the distortion from taxation by allocating taxes over time ${ }^{18}$. Let $\Gamma_{i}(i=1,2)$ be the tax revenue obtained by the government in period $i$. Following Barro (1979), the excess burden or deadweight loss of taxation is represented by the loss function $W\left(\Gamma_{i}\right)$, where $W(0)=0, W^{\prime}>0, W^{\prime \prime}>0 .{ }^{19}$ Here the degree of risk-aversion of taxpayers does not affect the basic intuition that, because of the convex excess burden in its objective function, the government should smooth tax rates. Because of the nature of the loss function of taxes, the government should act as if it were risk averse, even if all the households are risk neutral. Thus, the assumption of risk-neutral residents helps to focus on the government's problem.

\subsection{Equilibrium under Commitment}

In this sub-section it is assume $d$ that the government can credibly commit to repaying its domestic and external debt obligations in the second period. This solution will serve as the benchmark case.

Proposition 1: Under precommitment, optimal domestic and foreign borrowing ensures expected distortion smoothing. Domestic and foreign interest rates will be equalized.

Optimal government borrowing attempts to smooth tax distortions subject to the budget constraints. ${ }^{20}$ The government's problem is to maximize

\footnotetext{
${ }^{17}$ The case with default is dealt with in section 5 .

${ }^{18}$ I assume that there are no market imperfections other than those caused by the government's need to raise revenues.

${ }^{19}$ An important assumption is that the distortion in period $i$ does not depend on expected future tax collections.

${ }^{20}$ Sargent (2000) highlights the isomorphism between consumption-smoothing models and tax-smoothing models. He shows that every issue in the consumption smoothing models surfaces in a corresponding tax smoothing model.
} 


$$
\underset{B_{1}, F_{1}}{\operatorname{Max}}-W\left(\Gamma_{1}\right)-\delta W\left(\Gamma_{2}\right) \quad 0<\delta<1
$$

subject to the following period 1 and period 2 constraints, respectively:

$$
\begin{aligned}
& \mathrm{T}_{1}=G_{1}-B_{1}-F_{1} \\
& \mathrm{~T}_{2}=\left(1+r_{f}\right) F_{1}+\left(1+r_{b}\right) B_{1}+G_{2}
\end{aligned}
$$

Since government bonds are the only saving vehicle, domestic capital market equilibrium requires that the private agent's financial wealth equal the government's dome stic debt (in per capita terms), that is $S_{1}=B_{1}$, which implies that

$$
B_{1}=Y_{1}-\mathrm{T}_{1}-C_{1}-W\left(\Gamma_{1}\right)
$$

The government will internalize domestic and foreign creditors' reaction functions while making its optimal policy announcement. Under precommitment, domestic creditors will solve the program (1) - (4). Foreign investors will solve the program (6) - (6.2). The assumption of competitive risk-neutral international investors implies that in equilibrium the interest rate on external debt must be equal to the risk free international interest rate, that is, $r_{f}=r^{*}$.

Internalizing the reaction of investors, the government maximizes its objective function in (7) subject to constraints (8) and (9). Also, there is an external debt constraint, $F_{1} \leq f\left[B_{1}, Y_{1}\right]$, which depends on the level of domestic debt as well as the first period GDP. This constraint simply specifies that the sovereign will not choose to repudiate on its external debt. As long as the external debt constraint is not binding, the first order conditions for this maximization problem yield the following:

$$
W^{\prime}\left(\Gamma_{1}\right)=\delta\left(1+r_{b}\right) E W^{\prime}\left(\Gamma_{2}\right)
$$


and

$$
r_{b}=r_{f}
$$

Equation (11) determines the optimal fiscal policy in terms of taxes and government borrowing. Taxes are smoothed over time through public debt issuance, in a path that slopes according to the relative magnitudes of $\delta$ and $r_{b}$. In addition, as long as the external debt constraint is not binding, domestic and world interest rates are equal. The government will borrow up to the point where the cost of borrowing in domestic and foreign markets is equalized. ${ }^{21}$

\section{Incentive Problems and Selective Default}

We now consider the case where the government can no longer credibly commit to repaying its debt obligations in every possible state of nature in the second period. Under certain parameter combinations, and for certain values of the state variables, it is possible that the sovereign chooses to default rather than honoring its debt obligations. In this setup, debt contracts are not enforceable as the sovereign can choose to default on its debt contracts if it finds it optimal to do so. As described in the previous section, the country can borrow in both domestic and external markets. A key characteristic of the model is the possibility of default on both domestic and external debt. In the context of sovereign debt, it is important to distinguish between a domestic creditor and a foreign creditor, since both might have different possibilities to sanction a government that is unwilling (or unable) to repay. We assume that the identity of debt holders can be observed once the debt is issued. This allows for the possibility of segmented markets in which the government can selectively default on one class of its obligations (i.e. domestic or foreign).

For simplicity, output in the first period is normalized to 1 . In the second period, the economy receives stochastic exogenous endowment $y_{2}$, which is the realization of the random variable $Y:[\underline{y}, \bar{y}]$. The cumulative distribution function of $Y_{2}$ is $F\left(y_{2}\right)$ and the density function is $f\left(y_{2}\right)$. It is assumed that $\underline{y}>0$. Throughout this section, we will assume that there is a benevolent government whose objective function is to minimize the excess burden of

\footnotetext{
${ }^{21}$ When the external debt constraint becomes binding the domestic interest rate will jump. This change in the domestic interest rate will reflect the need for the sovereign to rely (ma rginally) only on domestic finance.
} 
distortionary taxes, and it can selectively default on one class of bondholders. The aim of this sub-section is to characterize the optimal debt structure chosen by the sovereign in the first period.

The sequence of events in the model is as follows. Loans are taken out at the beginning of the first period (to augment period 1 government spending) and are repaid with interest at the beginning of the second period. Suppose the sovereign borrows an amount $F_{1}$, at a contractual interest rate $r_{f}$, in foreign capital markets and an amount $B_{1}$, at a contractual interest rate $r_{b}$, from domestic residents in the first period. At the beginning of the second period, output is realized and is observed by all the participants in the economy: domestic creditors, foreign creditors and the government. After the output is realized, the debtor decides whether to default or not (and on what class of obligations to default on). If a bad shock is realized in period 2, default occurs. Default is defined as any failure to meet contractually stated obligations on time and in full. In case of default, a penalty is inflicted upon the borrowing country.

Default costs are modeled as a fraction of output $\lambda y_{2}$. Following Bolton and Jeanne $(2005)^{22}$, this default cost can be decomposed into two components:

$$
\lambda y_{2}=\alpha y_{2}+\beta y_{2}
$$

The first component is a deadweight cost that the country must bear when it defaults on its debt obligations. It can be interpreted as a reputational cost of default, or output loss resulting from a banking crisis or capital flight. The second component is a sanction that foreign creditors impose on the defaulting country (for example, the output loss resulting from litigation by creditors in foreign countries, or from trade sanctions). If the sovereign defaults on its domestic debt obligations, it only bears the deadweight cost, $\alpha y_{2}$. Thus, defaulting on either type of debt results in payment of the deadweight cost, $\alpha y_{2}$, while sanctions $\beta y_{2}$ are imposed only if the sovereign defaults on its external debt obligations. The assumption that default may reduce output can be

\footnotetext{
22 The modeling of default costs is similar to that used by Bolton and Jeanne (2005) to analyze the moral hazard problem associated with debt dilution. The emphasis here, however, is quite different and focuses on the features of domestic and external borrowing.
} 
rationalized by the common view that after default there is a disruption in the countries' ability to engage in international trade, which in turn reduces the value of output (Rose, 2002; Cole and Kehoe, 2000; Bulow and Rogoff, 1989). Also, Sturzenegger (2002), in a study of defaults in the 1980s, finds evidence of a 4 percent cumulative drop in output over the 4 years immediately following a default.

Several points are worth noting about the penalty structure utilized in this model. First, this formulation attempts to capture in a simple way the fact that domestic and foreign creditors have different ways of punishing the government. Second, since the investors' punishment is independent of the magnitude of the default, it is optimal for the government to repudiate the entire stock of debt. Third, following Bolton and Jeanne (2005), we assume that the only way that the sovereign discriminates between different classes of creditors is through selective default. ${ }^{23}$ Although this assumption precludes the more realistic possibility of the sovereign negotiating with both types of creditors simultaneously, it allows us to focus on the implications of unequal creditor treatment for the ex ante equilibrium of the debt market.

\subsection{Default Decisions}

To define equilibrium in this framework, we solve the model backwards, starting from period 2. We determine the repayment and default decisions of the sovereign, taking the stock of domestic $\left(B_{1}\right)$ and external debt $\left(F_{1}\right)$ as given. In period 2, there are three pos sible scenarios faced by the sovereign:

(i) Fully repay both domestic and external debt;

(ii) Selective default on either kind of debt; or

(iii) Default on both kinds of debt.

If the sovereign defaults on its external debt obligations it receives a payof fof $(1-\lambda) y_{2}-R_{b} B_{1}$. On the other hand, if it defaults on both its domestic and foreign debt its payoff will be given

\footnotetext{
${ }^{23}$ Although the focus of their analysis is on renegotiable and non-renegotiable debt. Bolton and Jeanne (2005) simplify the situation in the extreme by assuming that 'non-renegotiable' debt is impossible to restructure. This assumption then implies that debt restructuring, if it occurs, involves renegotiable debt only. Although it would be more realistic to let the sovereign negotiate simultaneously with both types of creditors, such a model of trilateral bargaining is far from straightforward.
} 
by $(1-\lambda) y_{2}$. This implies that for the sovereign, selective default on foreign debt is unambiguously dominated by full default. Thus, either the government defaults on both kinds of debt obligations, or defaults selectively on domestic debt. The case of selective default on foreign debtcan effectively be ruled out. Intuitively, once the government has incurred the reputational cost of default and paid the sanctions, it has no incentive to make any payments to its domestic creditors.

Let $R_{b} B_{1}$ and $R_{f} F_{1}$ be the repayment due on domestic and external debt in period 2, respectively. ${ }^{24}$ Whether default takes place for a given value of $y_{2}$ depends on whether $\left(R_{b} B_{1}+R_{f} F_{1}\right)$ is greater than $\lambda y_{2}$ for that value of $y_{2}$. We can partition the range of $y_{2}$ in an interval where this will be the case and in an interval where it will not. If the country defaults on both kinds of delt it suffers a loss of $\lambda y_{2}$. So if $R_{b} B_{1}+R_{f} F_{1} \leq \lambda y_{2}$ the country fully repays the two types of debt. If, on the other hand, $R_{b} B_{1}+R_{f} F_{1}>\lambda y_{2}$ we have the following two scenarios to consider: First, if $R_{f} F_{1}>\beta y_{2}$ the country will default on both kinds of debt which costs $\lambda y_{2}$. This is less costly than a partial default on domestic debt which would cost $R_{f} F_{1}+\alpha y_{2}>\lambda y_{2}$. Second, if $R_{f} F_{1} \leq \beta y_{2}$ the government defaults on its domestic debt obligations. We assume that the government prefers a partial default on its domestic debt to a full default.

Thus, selective default on domestic debt occurs if and only if

$$
\frac{R_{f} F_{1}}{\beta} \leq y_{2}<\frac{R_{b} B_{1}+R_{f} F_{1}}{\lambda}
$$

This is possible only if $\frac{R_{f} F_{1}}{\beta}<\frac{R_{b} B_{1}+R_{f} F_{1}}{\lambda}$, which in turn requires that

\footnotetext{
${ }^{24}$ Thus, $R_{b}$ and $R_{f}$ are the contractual interest factors on domestic and external debt, respectively.
} 


$$
\frac{R_{f} F_{1}}{\beta}<\frac{R_{b} B_{1}}{\alpha}
$$

If this condition is not satisfied, there are only two other cases possible:

(i) $R_{b} B_{1}+R_{f} F_{1} \leq \lambda y_{2}$ and the government repays all its debts, and

(ii) $R_{b} B_{1}+R_{f} F_{1}>\lambda y_{2}$ and the government defaults on both domestic and foreign debt obligations and incurs a penalty of $\lambda y_{2}$.

Proposition 2 The sovereign's period 2 repayment strategy is as follows:

(a) Full repayment: If $\frac{R_{b} B_{1}+R_{f} F_{1}}{\lambda} \leq y_{2}$ the country fully repays its domestic and foreign debt.

(b) Selective default: If $\frac{R_{f} F_{1}}{\beta} \leq y_{2}<\frac{R_{b} B_{1}+R_{f} F_{1}}{\lambda}$ the country defaults on its domestic debt and repays its foreign debt in full.

(c) Full default: If $\frac{R_{f} F_{1}}{\beta}>y_{2}$ the country defaults on both domestic and external debt.

Proof: See discussion above. !

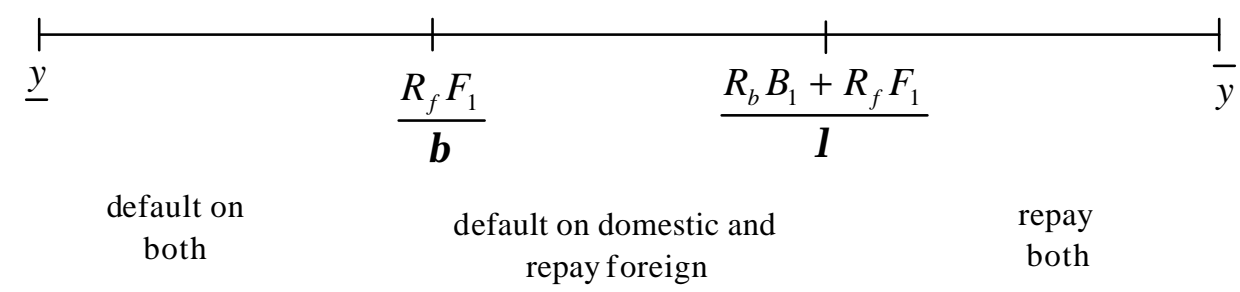

Figure 1: Repayment strategy of the sovereign 
Proposition 1 implies that bonds held by external creditors are effectively senior to bonds held by domestic creditors. In the case of partial default, the allocation of repayment between external and domestic bondholders is as if the former enjoyed strict seniority over the latter. This effective seniority would in turn imply that external bondholders should have a higher expected recovery ratio than domestic bondholders. Thus, we would expect the interest rate spread on external bonds to be lower than that on domestically placed bonds.

\subsection{Foreign Creditors}

The net transfers to external creditors in the second period can be written as

$$
P_{2}^{f}=\left\{\begin{array}{lll}
R_{f} F_{1} & \text { if } & y_{2}>\frac{R_{f} F_{1}}{\beta} \\
\beta y_{2} & \text { if } & y_{2} \leq \frac{R_{f} F_{1}}{\beta}
\end{array}\right.
$$

The probability of default on external debt is given by

$$
\pi^{d}\left(F_{1}, y_{2}\right)=\int_{\underline{y}}^{R_{f} F_{1} / \beta} f\left(y_{2}\right) d y_{2}
$$

The probability of default on external debt is a function of the state of the economy in the second period. It is a function of the stock of external debt $F_{1}$ and the level of endowment $y_{2}$. The probability of default is increasing in the stock of external debt as more debt implies a wider range of endowment realizations for which the sovereign prefers to default. ${ }^{25}$

${ }^{25}$ To see this, let $\tilde{y}=\frac{R_{f} F_{1}}{\beta}$. Then from (13) $\frac{\partial \pi^{d}\left(F_{1}, y_{2}\right)}{\partial F_{1}}=f(\tilde{y}) \cdot \frac{\partial \tilde{y}}{\partial F_{1}}=f(\tilde{y}) \cdot \frac{R_{f}}{\beta}>0$. 
Under 'no commitment,' the maximization problem of the foreign investors can be characterized as follows:

$$
\underset{\left\{c_{1}^{*}, c_{2}^{*}, x_{1}^{*}, F_{1}\right\}}{\operatorname{ax}} \quad U^{*}=u\left(c_{1}^{*}\right)+E \delta u\left(c_{2}^{*}\right)
$$

subject to

$$
\begin{aligned}
& c_{1}^{*}=a_{0}^{*}-x_{1}^{*}-F_{1} \\
& c_{2}^{*}=\left(1+r^{*}\right) x_{1}^{*}+\left(1-\pi^{d}\right)\left(1+r_{f}\right) F_{1}
\end{aligned}
$$

where $c_{i}^{*}$ denotes the consumption of foreign investors in period $i . F_{i}$ and $x_{i}^{*}$ denote the international investor's holdings of government bonds and risk-free international assets in period $i$, respectively. The first order conditions for this problem imply

$$
\left(1+r^{*}\right)=E\left(1+r_{f}\right)\left\{\left[1-\pi^{d}\left(F_{1}, y_{2}\right)\right]-F_{1} \pi_{F_{1}}^{d}\left(F_{1}, y_{2}\right)\right\}
$$

Proposition 3: In the presence of default risk, foreign bonds will exhibit a positive interest spread. The spread is a function of the state variables of the model economy.

Proposition 3 follows directly from equations (13) and (15.3).

If there are no sovereign risk considerations, then competition among lenders will imply $r_{f}=r^{*}$. However, if the probability of default $\int_{\underline{y}}^{R_{f} F_{1} / \beta} f\left(y_{2}\right) d y_{2}$ is positive, the interest rate charged on the sovereign's external debt will be higher than the international risk-free rate, i.e. $r_{f}>r^{*}$, since international investors must now be compensated for the possibility of debt repudiation. Thus, under no commitment the stock of external debt will differ from that under precommitment, as shown by equation (15.3). This is due to the term associated with the probability of default, and the term associated with the effect on the probability of default of a unit increase in the stock of foreign debt. 
The assumption of competitive risk-neutral international investors implies that in equilibrium the interest rate on government debt should be such that it yields an expected return equal to the risk-free return,

$$
\left(1+r^{*}\right) F_{1}=E\left\{P_{2}^{f}\right\}
$$

From expression (16) and the fact that the borrower repudiates whenever $R_{f} F_{1} \geq \beta y_{2}$, we have $\left(1+r^{*}\right) F_{1}=E\left\{P_{2}^{f}\right\} \leq \beta y_{2}$. Therefore, the maximum amount that foreign creditors are willing to lend is given by

$$
F_{1} \leq \frac{\beta y_{2}}{\left(1+r^{*}\right)}
$$

Thus, the higher the costs of the penalty, the higher is the credit ceiling. For each additional dollar of the default penalty, the debtor gets $\frac{1}{1+r^{*}}$ additional dollars of foreign debt $F_{1}$. Given tax obligations of domestic residents, foreign lenders can restrict loan amounts to ensure that repayment is in the borrower's interest.

\subsection{Domestic Creditors}

The government can no longer commit to fulfilling its domestic debt obligations in all states of nature. In this case, the net transfers to domestic creditors in the second period can be written as:

$$
P_{2}^{b}=\left\{\begin{array}{lll}
R_{b} B_{1} & \text { if } & y_{2}>\frac{R_{b} B_{1}+R_{f} F_{1}}{\lambda} \\
0 & \text { if } & y_{2} \leq \frac{R_{b} B_{1}+R_{f} F_{1}}{\lambda}
\end{array}\right.
$$

The probability of default on domestic debt can be written as 


$$
p^{d}\left(B_{1}, F_{1}, y_{2}\right)=\int_{\underline{y}}^{\left(R_{b} B_{1}+R_{f} F_{1}\right) / \lambda} f\left(y_{2}\right) d y_{2}
$$

It is a function of the total stock of debt $\left(B_{1}+F_{1}\right)$ and the level of endowment $y_{2}{ }^{26}$

The representative consumer maximizes the following intertemporal utility function:

$$
U=\sum_{i=1}^{2} \delta^{\mathrm{i}-1}\left[u\left(C_{i}\right)+v\left(G_{i}\right)-W\left(\Gamma_{i}\right)\right]
$$

with respect to $C_{1}$ and $C_{2}$. The maximization problem is subject to the following budget constraints:

$$
\begin{aligned}
& C_{1}=y_{1}-\Gamma_{1}-W\left(\Gamma_{1}\right)-S_{1} \\
& C_{2}=\left[1-p^{d}\left(B_{1}, F_{1} ; y_{2}\right)\right]\left(1+r_{b}\right) S_{1}+y_{2}-\Gamma_{2}-W\left(\Gamma_{2}\right)
\end{aligned}
$$

The first order conditions imply the following equation:

$$
u^{\prime}\left(C_{1}\right)=E \delta\left(1+r_{b}\right)\left[1-p^{d}\left(B_{1}, F_{1}, y_{2}\right)\right] u^{\prime}\left(C_{2}\right)
$$

This is the standard Euler equation adjusted for the risk of default.

\footnotetext{
${ }^{26}$ The probability of default on domestic debt is an increasing function of the stock of total debt. To see this, let $\hat{y}=\frac{R_{b} B_{1}+R_{f} F_{1}}{\lambda}$. Then from (19), $\frac{\partial p^{d}\left(B_{1}, F_{1}, y_{2}\right)}{\partial B_{1}}=f(\hat{y}) \cdot \frac{\partial \hat{y}}{\partial B_{1}}=f(\hat{y}) \cdot \frac{R_{b}}{\lambda}>0$. Also, $\frac{\partial p^{d}\left(B_{1}, F_{1}, y_{2}\right)}{\partial F_{1}}=f(\hat{y}) \cdot \frac{\partial \hat{y}}{\partial F_{1}}=f(\hat{y}) \cdot \frac{R_{f}}{\lambda}>0$.
} 


\subsection{Equilibrium Borrowing with Selective Default}

In the first period, the government can choose between various combinations of taxes, and domestic and external borrowing to finance its fiscal outlays. In the second period only taxes are available to finance both debt repayments and expenditure on the public good. For simplicity, the initial outstanding domestic and external debt is assumed to be zero. The government's budget constraint in periods 1 and 2 can now be written as

$$
\begin{aligned}
& \Gamma_{1}=G_{1}-B_{1}-F_{1} \\
& \Gamma_{2}=P_{2}^{f}+P_{2}^{b}+G_{2}
\end{aligned}
$$

where, $P_{2}^{f}$ and $P_{2}^{b}$ is the actual repayment to external and domestic creditors in the second period, respectively. ${ }^{27}$

The optimal taxation literature suggests that governments could improve welfare if they used debt management to reduce unexpected fluctuations in the tax rate. Changes in taxation are costly because the welfare loss from taxation rises more than proportionately with changes in the tax rate. A benevolent government will thus try to equalize the marginal social cost of taxation across dates and states of nature. However, in the presence of shocks to spending and output, taxes will need to change over time in order to maintain fiscal solvency. Theoretically, the government could keep the tax rate constant if it could hedge against the impact of shocks on its finances by issuing state-contingent debt. In such a case, the effect of any shock could be completely offset by changes in debt servicing costs. However, governments usually do not issue state-contingent debt. In reality, returns on government debt are never state contingent except through the possibility of default when the economy is hit by a bad shock. The debt contract with default can be viewed as a special form of the public debt contracts with state-contingent returns. $^{28}$

\footnotetext{
${ }^{27} P_{2}^{f}$ and $P_{2}^{b}$ are as defined in equation (12) and (18), respectively, and denote the realized returns i.e. inclusive of any repudiation.

${ }^{28}$ Public debt contracts with state-contingent retums were analyzed in Chari, Christiano and Kehoe (1994), and discussed in Barro (1995).
} 
It is worth emphasizing here that markets in this setup are incomplete, as not only is there an endogenous default risk, but the set of assets available to the economy are not sufficient to insure away the idiosyncratic shocks to endowment. The option of defaulting brings partial state contingency to the economy. In the absence of any contract enforcement mechanism in the model economy, the sovereign can decide whether to repay its debts or to default (selectively or in full). Thus, in this sense default has a state-contingent (i.e. insurance) mechanism which would be absent from a risk-free bond.

As described earlier, taxes are distortionary and the government minimizes the distortion from taxation by allocating taxes over time. The second period output is subject to stochastic disturbances. Shocks to the economy generally require unexpected changes in the path of taxes. Good states of nature allow for tax cuts and bad states require tax increases. Thus, the cost of taxation also varies with the state of nature- raising taxes being more costly in the bad states of nature. Because the welfare losses from taxation increase more than linearly with changes in taxes, the total loss from raising taxes in one period and then lowering them in the next period will tend to be higher than if taxes were the same over both periods (for a given total amount of taxation over the two periods). Thus, optimal government borrowing attempts to smooth tax distortions subject to the budget constraints. The government's problem is to maximize

$$
\begin{gathered}
\operatorname{Max}_{B_{1}, F_{1}} W=-W\left(\Gamma_{1}\right)-\delta W\left(\Gamma_{2}\right) \\
\text { or, } \quad \operatorname{Max}_{B_{1}, F_{1}}-W\left(G_{1}-B_{1}-F_{1}\right)-\delta \int_{\underline{y}}^{\bar{y}} W\left(P_{2}^{f}+P_{2}^{b}+G_{2}\right) f\left(y_{2}\right) d y_{2}
\end{gathered}
$$

The first order condition for optimal foreign borrowing is given by

$$
W^{\prime}\left(\Gamma_{1}\right)-\delta\left(1+r^{*}\right) \int_{R_{f} F_{1} / \beta}^{\bar{y}} W^{\prime}\left(\Gamma_{2}\right) f\left(y_{2}\right) d y_{2} \cdot \frac{1}{\int_{R_{f} F_{1} / \beta}^{\bar{y}} f\left(y_{2}\right) d y_{2}}=0
$$

which can also be written as 


$$
\int_{R_{f}}^{\bar{y}}\left\{W^{\prime}\left(\Gamma_{1}\right)-\delta\left(1+r^{*}\right) W^{\prime}\left(\Gamma_{2}\right)\right\} f\left(y_{2}\right) d y_{2}=0
$$

The first term in equation (26) captures the first period welfare gain associated with funding one unit of fiscal expenditure by foreign borrowing instead of raising taxes. The second expression is the expected deadweight loss in the second period that comes from having to raise future taxes to repay external debt.

If the country always repays its external debt, then $\int_{\frac{R_{f} F_{1}}{\beta}}^{\bar{y}} f\left(y_{2}\right) d y_{2}=1$. Equation (26) can be written as

$$
W^{\prime}\left(\Gamma_{1}\right)=\delta\left(1+r^{*}\right) E\left[W^{\prime}\left(\Gamma_{2}\right)\right]
$$

To simplify, assume that the excess burden is quadratic, that is $W\left(\Gamma_{i}\left(t_{i}\right)\right)=\left(\frac{\lambda}{2} t_{i}^{2}\right)$. Thus, a tax at rate $t$ yields a net tax revenue of $\Gamma_{i}(t)=y_{i}\left[t-\frac{\lambda}{2} t^{2}\right] ; \lambda \geq 0$. Therefore, if $\delta=\frac{1}{1+r^{*}}$, then equation (27) implies tax smoothing over time $E\left(t_{2}\right)=t_{1}$, as in Barro (1979). Thus, optimal foreign borrowing ensures distortion smoothing between period 1 and the states of nature in period 2 in which full repayment occurs.

The first order condition for optimal domestic borrowing is given by

$$
W^{\prime}\left(\Gamma_{1}\right)-\delta\left(1+r_{b}\right) \int_{\left(R_{b} B_{1}+R_{f} F_{1}\right) / \lambda}^{\bar{y}} W^{\prime}\left(\Gamma_{2}\right) f\left(y_{2}\right) d y_{2}=0
$$

The first term in equation (28) captures the first period welfare gain associated with funding one unit of fiscal expenditure through domestic borrowing instead of raising taxes. The second 
expression represents the expected deadweight loss in the second period that comes from having to raise future taxes to repay domestic debt obligations.

The optimal allocation of debt between domestic and foreign creditors canthus be viewed as the government's purchase of insurance. The presence of both domestic and external debt facilitates intertemporal consumption smoothing in the event of default. The option of defaulting on domestic debt in the second period, and thus not having to raise taxes, will help cushion the fall in second-period consumption should a bad shock trigger default. A bad shock in the second period reduces output and triggers default. These are also the states of nature where the marginal cost of public funds is high. Thus, when tax collection is costly, the government can strategically default on only one class of its obligations in order to minimize the excess burden of distortionary taxes. A country characterized by volatile output, tax collection costs and sovereign risk will thus want to borrow in domestic markets as well as in international capital markets.

\section{Conclusions and Implications}

The outstanding volume of domestic debt issued by emerging markets has increased significantly relative to international debt in recent years. The increasing significance of public sector bonds issued in domestic markets argues for the importance of analyzing the considerations that affect a government's decision to borrow from home or abroad. Furthermore, emerging markets have defaulted on both domestic and foreign debt in recent years. Countries have also defaulted differentially on domestic and foreign debt, and even on different types of debt within these two classes. Standard economic models of sovereign debt mainly focus on how the actions of foreign creditors influence the default decisions of sovereigns, either through increased reputational costs or trade sanctions. Very little attention has been paid to the response of domestic creditors, or to the relative standing of the two classes of creditors. In contrast to this one-sided focus, this paper adds to a new theoretical literature that points at the possibility of default on domestic debt and the ability of domestic creditors to punish the sovereign.

The model presented in this paper introduces a distinction between domestic and external borrowing, and focuses on the problem of raising domestic revenue in order to service debt obligations. We allow for the possibility of default on both domestic and foreign debt, and 
default is costly. The two classes of creditors are assumed to have different abilities to punish the government in the event of default, and this in turn creates a gap in the expected default costs to the sovereign and hence a differential in its propensity to default on its domestic versus foreign debt.

The motivation for debt management in this paper is to minimize the welfare losses arising from distortionary taxation. Optimal government borrowing attempts to smooth tax distortions. Results show that the presence of both foreign and domestic debt facilitates intertemporal consumption smoothing in the event of default. The option of defaulting on domestic debt helps cushion the fall in consumption in the second period. Thus, in the presence of distortionary taxation, the sovereign can strategically default on one class of creditors in order to minimize the excess burden of taxes.

This research highlights two key practical lessons for policymakers in the realm of international finance. First, the results from this research and the case studies discussed make it clear that when governments run out of money they often treat domestic and foreign creditors differently. Despite important concerns about inter-creditor equity, the ability to treat domestic and foreign creditors differently can be seen as a policy option for governments in financial crisis. One possible way of dealing with this would be a sovereign bankruptcy regime capable of ensuring equal treatment among identical debt instruments. ${ }^{29}$ Admittedly, this is difficult to say the least. Second, the significant increase in the volume of domestic debt issued by emerging market entities relative to international debt calls for a new way of framing the core issues that arise in financial crises. An in-depth assessment of risk and fiscal sustainability must be based on a comprehensive view of the country's debt stock - that is, including both domestic and foreign debt.

\footnotetext{
${ }^{29}$ See, for example, Bolton and Skeel (2004), and Gelpern and Setser (2004).
} 


\section{References}

Aizenman, J., K. Kletzer, and B.Pinto. 2002. "Sargent-Wallace Meets Krugman-Flood-Garber, or: Why Sovereign Debt Swaps Don't Avert Macroeconomic Crises." NBER Working Paper No. 9190.

Aizenman, J., M. Gavin, and R. Hausmann. 2000. “Optimal Tax and Debt Policy with Endogenously Imperfect Creditworthiness.” Journal of International Trade and Economic Development 9(4): 367-395.

Angeletos, G.M. 2002. "Fiscal Policy with Noncontingent Debt and the Optimal Maturity Structure." Quarterly Journal of Economics 117(3): 1105-1131.

Barro, R. J. 1995. “Optimal Debt Management.” NBER Working Paper No.5327.

Barro, R. J. 1979. "On the Determination of the Public Debt.” Journal of Political Economy 87(5): 940-971.

Beaugrand, P., B. Loko, and M. Mlachila. 2002. "The Choice Between External and Domestic Debt in Financing Budget Deficits: The Case of Central and West African Countries." IMF Working Paper No. 02/79.

Bohn, H. 1988. “Why do We Have Nominal Debt?” Journal of Monetary Economics 21: 127-40.

Bohn, H. 1990. "Tax Smoothing with Financial Instruments.” American Economic Review 80(5): 1217-1230.

Bohn, H. 1990. "A Positive Theory of Foreign Currency Debt.” Journal of International Economics 29: 273-92.

Bolton, P. and O. Jeanne. 2005. "Structuring and Restructuring of Sovereign Debt: The Role of Seniority." NBER Working Paper No. 11071. 
Bolton, P. and D. A. Skeel, Jr. 2004. "Inside the Black Box: How Should a Sovereign Bankruptcy Framework Be Structured?” Emory Law Journal 763.

Bulow, J. and K. Rogoff. 1989. “Sovereign Debt: Is to Forgive to Forget?” American Economic Review 79: 43-50.

Calvo, G. 1988. "Servicing the Public Debt: The Role of Expectations." American Economic Review 78: 647-61.

Calvo, G. 2000. "Betting against the State: Socially Costly Financial Engineering." Journal of International Economics 51(1): 5-19.

Calvo, G. and P.E. Guidotti. 1990. "Credibility and Nominal Debt.” IMF Staff Papers 37: 612635.

Calvo, G. and P.E. Guidotti. 1992. “Optimal Maturity of Nominal Government Debt: An Infinite Horizon Model.” International Economic Review 33, November, 895-919.

Chari, V.V., L.J. Christiano, and P.J. Kehoe. 1994. "Optimal Fiscal Policy in a Business Cycle Model." Journal of Political Economy 102(4): 617-652.

Cohen, D. 1987. "External and Domestic Debt Constraints of LDCs: A Theory with a Numerical Application to Brazil and Mexico.” In Global Macroeconomics, edited by R. Bryant and R.

Portes. Mc Millan: 279-299.

Cohen, D. 1991. Private Lending to Sovereign States: A Theoretical Autopsy. The MIT Press.

Cole, H.L. and T. Kehoe. 2000. "Self-Fulfilling Debt Crises." Review of Economic Studies Vol. 67, 91-116. 
De Fontenay, P., G.M. Milesi-Ferretti, and H. Pill. 1995. “The Role of Foreign Currency Debt in Public Debt Management.” IMF Working Papers No.95/21

Dooley, M. and M. R. Stone. 1993. "Endogenous Creditor Seniority and External Debt Values." IMF Staff Papers, Vol. 40, No. 2.

Drazen, A. 1998. "Towards a Political-Economic Theory of Domestic Debt." In The Debt Burden and Its Consequences for Monetary Policy, edited by G. Calvo and M. King. St. Martin's Press: $159-76$.

Easterly, W. R. 1989. "Fiscal Adjustment and Deficit Financing During the Debt Crisis.” In Dealing with the Debt Crisis, edited by Ishrat Husain and Ishac Diwan. Washington: World Bank: 91-113.

Eichengreen, B. 2003. "Restructuring Sovereign Debt." Journal of Economic Perspectives 17(4), 75-98.

Gelpern, A. and B. Setser. 2004. "Domestic and External Debt: The Doomed Quest for Equal Treatment." Georgetown Journal of International Law 35(4).

Gray, S. and D. Woo. 2000. "Reconsidering External Financing of Domestic Budget Deficits: Debunking Some Received Wisdom.” IMF Policy Discussion Paper 00/8.

Guidotti, P. E. and M.S. Kumar. 1991. "Domestic Public Debt of Externally Indebted Countries." Occasional Paper No. 80.

IMF 2003. "Russia Rebounds.” Manuscript

Kremer, M. and P. Mehta. 2000. “Globalization and International Public Finance.” NBER Working Paper No. 7575. 
Lucas, R. E. and N.L. Stokey. 1983. "Optimal Fiscal and Monetary Policy in an Economy

Without Capital.” Journal of Monetary Economics, Vol. 12 (July): 55-94.

Mihaljek, D., M. Scatigna and A.Villar. 2001. "Recent Trends in Bond markets." BIS Papers No. 11.

Reisen, H. and Axel van Trotsenburg. 1988. "Developing Country Debt: The Budgetary and Transfer Problem" Paris: Organization for Economic Cooperation and Development, Development Center Studies.

Rose, A. 2002. "One Reason Countries Pay Their Debts: Renegotiation and International Trade." NBER Working Paper 8853.

Sargent, T. J. 2000. 'Comment on 'Fiscal Consequences for Mexico of Adopting the Dollar' by Christopher A. Sims, Mimeo.

Sturznegger, F. 2002. "Default Episodes in the 90s: Factbook and Preliminary Lessons." Mimeo Universidad Torcuato Di Tella.

Sturzenegger, F. and J. Zettelmeyer. 2004. "Haircuts: Estimating Investor Losses in Sovereign Debt Restructurings, 1998-2005.” IMF Working Paper 05/137.

Tomz, M. 2004. "Voter Sophistication and Domestic Preferences Regarding Debt Default." Mimeo Stanford University. 